\title{
'No collaboration, no trial; why collaborator opinion matters'
}

\author{
Claire Cochran*, The EAGLE Study Group \\ From 2nd Clinical Trials Methodology Conference: Methodology Matters \\ Edinburgh, UK. 18-19 November 2013
}

For a trial to be successful, site personnel must retain high commitment to a trial often over long periods of time. Little evidence exists, however, to guide what type of communication/training activities should be adopted to help promote long-term collaboration. In this presentation, we report the role of focus groups to inform the appropriate choice of communication/training activities for a large international study.

EAGLE (Effectiveness, in Angle closure Glaucoma, of Lens Extraction) is an international multi-centre, pragmatic, randomised controlled trial (RCT). Within EAGLE trial data from participant questionnaires and clinical case report forms are uploaded onto the bespoke EAGLE website by collaborators at 31 sites worldwide. In order to elicit useful experiences and opinions from collaborators to inform future trial procedures, focus groups were conducted during a trial training event.

Group training days, rather than individual visits, were preferred as they provide an opportunity to network with peers and focus on the trial away from distraction of the everyday environment. Collaborator newsletters remain a popular way of maintaining trial profile at a group level; at individual level distributing tasks by regular brief emails encourages engagement. Web based data entry gives collaborators a sense of ownership over the data they collect, but thoughtful website design and (telephone) support is key to maintaining data quality. Collaborators like trials that mimic standard clinical care; they are perceived easier to recruit and retain patients than other explanatory trials. Barriers included complexity of the inclusion and exclusion criteria, and issues with local financial support.

Published: 29 November 2013

University of Aberdeen, Aberdeen, UK

(c) 2013 Cochran; licensee BioMed Central Ltd. This is an Open Access article distributed under the terms of the Creative Commons Attribution License (http://creativecommons.org/licenses/by/2.0), which permits unrestricted use, distribution, and reproduction in any medium, provided the original work is properly cited.
doi:10.1186/1745-6215-14-S1-P127

Cite this article as: Cochran and : 'No collaboration, no trial; why collaborator opinion matters'. Trials 2013 14(Suppl 1):P127.

Submit your next manuscript to BioMed Central and take full advantage of:

- Convenient online submission

- Thorough peer review

- No space constraints or color figure charges

- Immediate publication on acceptance

- Inclusion in PubMed, CAS, Scopus and Google Scholar

- Research which is freely available for redistribution

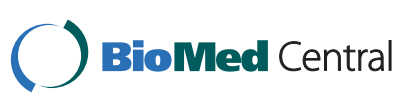

